\title{
PENGARUH UKURAN PERUSAHAAN, METODE AKUNTANSI, DAN STRUKTUR KEPEMILIKAN TERHADAP TAX AVOIDANCE PADA PERUSAHAAN MANUFAKTUR YANG TERDAFTAR DI BURSA EFEK INDONESIA PERIODE 2010-2013
}

\author{
Edeline \\ Institut Bisnis dan Informatika Kwik Kian Gie \\ claudiaedeline@yahoo.com \\ Amelia Sandra \\ Institut Bisnis dan Informatika Kwik Kian Gie \\ amelia.sandra@kwikkiangie.ac.id
}

\begin{abstract}
Tax is one source of country's revenue comes from the people. Efforts in this country instead of optimizing revenues is not without obstacles. The main obstacle in the context of state income tax in this sector is tax avoidance. The purpose of this research is to examine if firm size, accounting method, and ownership structure have an influence on tax avoidance in manufacturing companies listed in Indonesia Stock Exchange in period 2010-2013. This study uses observational methods on secondary data which obtained from the annual financial report and audited financial statements of companies. This study uses 27 manufacturing companies that listed in Indonesian Stock Exchange as a sample. This research uses purposive sampling method for sampling method. The analytical method used is Structural Equation Modelling (SEM) using a variance-based Partial Least Square (PLS). The results showed that firm size has a value of T-statistic for 2.521 where the value is greater than 1.96, accounting method has a value of $T$ statistic for 4.015 where the value is greater than 1.96, and ownership structure has a value of T-statistic for 1.759 where the value is smaller than 1.96. From the results of this study concluded that firm size and the accounting method have influence on tax avoidance. While the ownership structure found no effect on tax avoidance.
\end{abstract}

Keywords: Tax Avoidance, Firm Size, Accounting Method, Ownership Structure.

\section{PENDAHULUAN}

Pajak merupakan salah satu sumber pendapatan negara yang berasal dari rakyat. Dengan adanya pembayaran pajak, maka pemerintah dapat melakukan program-program pembangunan yang dapat dinikmati oleh rakyat (Pradipta dan Supriyadi, 2015). Pemerintah menggunakan pajak sebagai sumber pembiayaan 
negara dan target penerimaan pajak setiap tahun diharapkan terus meningkat. Pajak ditempatkan sebagai salah satu kewajiban dalam bernegara, yaitu sebagai sarana masyarakat untuk ikut berpartisipasi dalam rangka memenuhi target penerimaan negara sebagai sumber pembiayaan pembangunan. Bagi negara-negara yang ada di dunia ini, pajak merupakan unsur penting dan bahkan paling penting dalam rangka untuk menopang anggaran penerimaan negara. Oleh karena itu, pemerintah negara-negara di dunia ini begitu besar menaruh perhatian terhadap sektor pajak. Upaya mengoptimalkan penerimaan sektor pajak dapat dilakukan melalui usaha intensifikasi dan ekstensifikasi penerimaan jumlah pajak. Namun demikian, usaha untuk mengoptimalkan penerimaan sektor ini bukan tanpa kendala. Salah satu kendala dalam rangka optimalisasi penerimaan pajak adalah adanya penghindaran pajak (Tax Avoidance), bahkan tidak sedikit perusahaan yang melakukan penghindaran pajak (Budiman dan Setiyono, 2012).

Pajak merupakan hal yang menjadi perhatian penting karena beban pajak akan mengurangi laba bersih dan sudah menjadi rahasia umum perusahaan menginginkan pembayaran pajak seminimal mungkin (Kurniasih dan Sari, 2013). Meminimalisasi beban pajak dapat dilakukan dengan berbagai cara, mulai dari yang masih berada dalam bingkai peraturan perpajakan sampai dengan yang melanggar peraturan perpajakan. Meminimalkan kewajiban pajak yang tidak melanggar undang-undang sering disebut dengan Tax Avoidance (Sari, 2012). Tax avoidance yang dilakukan ini bersifat legal karena tidak melanggar perundangundangan perpajakan karena biasanya dilakukan dengan memanfaatkan hal-hal yang tidak diatur dalam undang-undang (Ngadiman dan Puspitasari, 2014).

Penghindaran pajak merupakan upaya untuk meminimalkan beban pajak menggunakan peraturan yang berlaku (Lawful), sedangkan penggelapan pajak (Tax Evasion) adalah upaya melakukan penghematan pajak dengan menggunakan cara yang melanggar ketentuan pajak (Ayu dan Hastuti, 2009). Oleh karena itu, persoalan 
penghindaran pajak diperbolehkan secara hukum selama sesuai dengan ketentuan undang-undang yang ada. Namun di sisi yang lain, penghindaran pajak juga tidak diinginkan karena dianggap dapat mengurangi penerimaan negara.

Banyak dari perusahaan-perusahaan maju yang melakukan tindakan penggelapan pajak dan penghindaran pajak untuk meminimalkan beban biaya pajak terutang yang harus dibayarkan kepada kas negara. Terkait dengan penghindaran pajak di Indonesia pada tahun 2005, terdapat 750 perusahaan Penanam Modal Asing yang diketahui melakukan penghindaran pajak dengan melaporkan rugi dalam waktu 5 tahun berturut-turut dan tidak membayar pajak (Budiman dan Setiyono, 2012). Sedangkan di Amerika paling tidak terdapat seperempat dari jumlah perusahaan telah melakukan penghindaran pajak yakni dengan membayar pajak kurang dari $20 \%$, padahal rata-rata pajak yang dibayarkan perusahaan mendekati 30\% (Dyreng, Hanlon, dan Maydew, 2007).

Terdapat banyak faktor yang dapat dikaitkan dengan tax avoidance.
Salah satu faktor penentu dalam pengambilan keputusan untuk melakukan tax avoidance adalah karakteristik perusahaan. Karakteristik tersebut dapat dilihat dari jenis usaha atau industri, struktur kepemilikan, tingkat likuiditas, tingkat profitabilitas, dan ukuran perusahaan (Subair, dalam Ngadiman dan Puspitasari 2014). Beberapa penelitian sebelumnya mencoba mengkaitkan faktor kondisi keuangan perusahaan terhadap tax avoidance, diantaranya memfokuskan pada ukuran perusahaan. Semakin besar ukuran suatu perusahaan maka semakin menjadi pusat perhatian dari pemerintah dan akan menimbulkan kecenderungan bagi para manajer perusahaan untuk berlaku patuh atau agresif (tax avoidance) dalam perpajakan (Kurniasih dan Sari, 2013).

Faktor lain yang diprediksi akan memengaruhi penghindaran pajak adalah penggunaan metode akuntansi. Menurut ketentuan perpajakan, terdapat beberapa metode akuntansi yang diatur secara tegas untuk digunakan oleh suatu perusahaan, diantaranya adalah 
metode penyusutan dan metode penilaian persediaan. Metode penyusutan yang diperbolehkan berdasarkan Undang-Undang Nomor 36 Tahun 2008 adalah metode garis lurus (straight line method) dan metode saldo menurun (declining balance method). Metode penyusutan akan memengaruhi besarnya biaya penyusutan suatu aset dalam laporan keuangan, termasuk berpengaruh terhadap pajak yang terutang dari suatu perusahaan. Hal ini dikarenakan beban penyusutan merupakan salah satu biaya yang dapat dikurangkan (deductible expense).

Pemilihan metode akuntansi persediaan untuk pelaporan keuangan guna memenuhi kebutuhan komersial di Indonesia diatur dalam Pernyataan Standar Akuntansi Keuangan (PSAK) No. 14 (Revisi 2008). Namun dalam kaitannya dengan pelaporan keuangan untuk kebutuhan fiskal, sesuai dengan Undang-Undang No. 10 Tahun 1994, persediaan dan pemakaian persediaan untuk perhitungan harga pokok dinilai berdasarkan harga perolehan yang dilakukan secara rata-rata atau dengan cara mendahulukan persediaan yang diperoleh pertama. Metode penilaian persediaan yang digunakan oleh suatu perusahaan akan memengaruhi besarnya harga pokok penjualan. Harga pokok penjualan merupakan pengurang pendapatan perusahaan yang akan memengaruhi besarnya pajak yang terutang dari suatu perusahaan.

Selain ukuran perusahaan dan metode akuntansi, struktur kepemilikan juga memiliki keterkaitan terhadap tax avoidance. Rusydi dan Martani (2014) menyatakan bahwa struktur kepemilikan dapat ditinjau dari kepemilikan keluarga, asing, dan pemerintah. Sedangkan, menurut Bachtiar (2015), struktur kepemilikan dapat ditinjau dari kepemilikan manajerial, kepemilikan institusional, dan kepemilikan publik. Namun, dalam perusahaan manufaktur struktur kepemilikan lebih terlihat jelas dari struktur kepemilikan institusional dan kepemilikan publik.

Kepemilikan institusional merupakan persentase saham yang dimiliki oleh pihak institusi perusahaan pada akhir tahun. Bachtiar (2015) menyatakan 
bahwa semakin besar proporsi saham yang dimiliki oleh pihak institusional membuat pengawasan terhadap manajemen juga akan meningkat dan keputusan yang diambil manajemen akan sesuai dengan kepentingan pemegang saham.

Kepemilikan publik menunjukkan besarnya kepemilikan saham perusahaan yang nilainya masingmasing kurang dari 5\% dan tidak terafiliasi dengan perusahaan (Santoso, 2014). Karena proporsi kepemilikan oleh publik tergolong kecil, mereka menjadi kurang memperhatikan kebijakan strategis perusahaan dan kurang termotivasi mengontrol kerja manajer. Kurangnya motivasi pemegang saham publik untuk mendapatkan laba yang sebesar-besarnya, menjadikan strategi pajak yang diambil kurang agresif (Puspita dan Harto, 2014).

Berdasarkan permasalahan penelitian yang telah diuraikan di atas, maka tujuan yang ingin dicapai oleh peneliti, yaitu:

1. Untuk mengetahui apakah ukuran perusahaan berpengaruh terhadap penghindaran pajak.
2. Untuk mengetahui apakah metode akuntansi berpengaruh terhadap penghindaran pajak.

3. Untuk mengetahui apakah struktur kepemilikan berpengaruh terhadap penghindaran pajak.

\section{TELAAH LITERATUR}

Teori Keagenan (Agency Theory)

Jensen dan Meckling (1976) menjelaskan hubungan agensi terjadi ketika satu orang atau lebih (principal) mempekerjakan orang lain (agent) untuk melakukan suatu jasa yang melibatkan pendelegasian wewenang untuk pengambilan keputusan kepada agen. Manajer (agen) sebagai pihak yang diberi wewenang oleh pemilik saham (prinsipal) memiliki tanggung jawab untuk dapat menjalankan perusahaan dengan sebaik mungkin sehingga dapat mencapai tujuan perusahaan dan menghasilkan tingkat return yang tinggi untuk pemilik saham. Namun, agency theory mengasumsikan setiap individu akan bertindak untuk kepentingan dirinya sendiri. Seperti sifat dasar manusia yang hanya mementingkan dirinya sendiri.Manajemen sebagai pengelola perusahaan lebih banyak 
mengetahui informasi internal dan juga going concern perusahaan dibandingkan dengan pemilik (pemegang saham).

Ketidakseimbangan luasnya informasi akan menimbulkan suatu kondisi yang disebut sebagai asimetri informasi (information asymmetry) (Rusydi dan Martani, 2014). Dengan memiliki informasi yang lebih banyak dibandingkan dengan pemilik saham, manajer akan terdorong untuk melakukan tindakan-tindakan yang bertujuan untuk mengejar kepentingannya semata.

Permasalahan keagenan dimana terdapat perbedaan kepentingan bagi agen dan prinsipal memicu timbulnya perilaku aggressive tax avoidance. Hal ini dikarenakan di satu sisi manajemen menginginkan peningkatan kompensasi melalui laba yang tinggi, sedangkan di sisi lainnya pemegang saham ingin menekan biaya pajak melalui laba yang rendah. Maka dalam rangka menjembatani agency problem ini timbul perilaku aggressive tax avoidance dalam rangka mengoptimalkan kedua kepentingan tersebut (Rusydi dan Martani, 2014).
Teori Akuntansi Positif (Positive Accounting Theory)

Watts dan Zimmerman (1990) menjelaskan prediksi kebijakan akuntansi yang hendak dipilih oleh perusahaan dalam kondisi tertentu. Dalam teori ini dipaparkan bahwa faktor-faktor ekonomi tertentu bisa dikaitkan dengan perilaku manajer atau para pembuat laporan keuangan. Tiga hipotesis utama dalam teori akuntansi positif (Watts dan Zimmerman, 1990), yaitu

(1) The Bonus Plan Hypothesis (antara manajemen dengan pemilik) Manajer perusahaan yang termotivasi oleh perolehan bonus akan cenderung menggunakan metode akuntansi yang meningkatkan laba saat ini. Laba yang meningkat akan mempengaruhi bonus yang diterima oleh manajer perusahaan.

(2) The Debt To Equity Hypothesis (antara manajemen dengan kreditur) Watts dan Zimmerman (1990) memprediksi bahwa semakin tinggi rasio hutang, maka semakin mungkin manajer memilih metode akuntansi untuk meningkatkan laba karena perjanjian utang mensyaratkan ketentuan-ketentuan yang harus dipatuhi oleh perusahaan, seperti 
menjaga posisi keuangan pada tingkat tertentu dan sebagainya.

(3) The Political Hypothesis (antara manajemen dengan pemerintah)

Perusahaan besar akan menggunakan metode akuntansi yang cenderung mengurangi laba yang dilaporkan. Perusahaan tidak ingin terlihat sebagai perusahaan dengan laba yang tinggi dengan tujuan untuk meminimalkan biaya politik yang harus mereka tanggung.

\section{Penghindaran Pajak (Tax Avoidance)}

Penghindaran pajak yang juga disebut sebagai tax planning, adalah proses pengendalian tindakan agar terhindar dari konsekuensi pengenaan pajak yang tidak dikehendaki. Penghindaran pajak adalah suatu tindakan yang benar-benar legal. Seperti halnya suatu pengadilan tidak dapat menghukum seseorang karena perbuatannya tidak melanggar hukum atau tidak termasuk dalam kategori pelanggaran atau kejahatan, begitu pula mengenai pajak yang tidak dapat dipajaki. Dalam hal ini, sama sekali tidak ada suatu pelanggaran hukum yang dilakukan dan malah sebaliknya akan diperoleh penghematan pajak dengan cara mengatur tindakan yang menghindarkan aplikasi pengenaan pajak melalui pengendalian faktafakta sedemikian rupa, sehingga terhindar dari pengenaan pajak yang lebih besar atau sama sekali tidak kena pajak (Zain, 2008: 49).

\section{Pengaruh Ukuran Perusahaan}

\section{Terhadap Penghindaran Pajak}

Besar kecilnya ukuran perusahaan dapat dilihat dari besarnya nilai equity, nilai penjualan atau nilai aktiva (Riyanto, dalam Ngadiman dan Puspitasari 2014). Dalam penelitian ini, ukuran perusahaan diukur dengan natural logarithm total asset dan natural logarithm total revenue. Semakin besar total asset dan total revenue mengindikasikan semakin besar pula ukuran perusahaan tersebut.

Hasil penelitian Waluyo, Basri, dan Rusli (2015) menyatakan bahwa ukuran perusahaan berpengaruh secara positif terhadap tax avoidance yang menunjukkan bahwa perusahaan besar lebih memiliki sumber daya yang lebih banyak dan aktivitas operasi yang lebih rumit sehingga terdapat celah-celah untuk 
dimanfaatkan dalam keputusan tax avoidance.

Berdasarkan hasil penelitian Kurniasih dan Sari (2013) diketahui bahwa ukuran perusahaan berpengaruh secara negatif terhadap tax avoidance yang menunjukkan bahwa semakin besar ukuran perusahaan maka perusahaan tersebut cenderung untuk meminimalkan tindakan penghindaran pajak. Hal ini dikarenakan perusahaan tidak selalu dapat menggunakan power yang dimilikinya untuk melakukan perencanaan pajak karena adanya batasan berupa kemungkinan menjadi sorotan dan sasaran dari keputusan regulator - political cost theory (Watts dan Zimmerman, 1978). Hasil penelitian ini didukung oleh penelitian yang dilakukan oleh Ngadiman dan Puspitasari (2014) yang menyatakan bahwa ukuran perusahaan memiliki pengaruh negatif dan signifikan terhadap tax avoidance.

\section{$\mathrm{H}_{1}$ : Ukuran Perusahaan berpengaruh terhadap penghindaran pajak.}

\section{Pengaruh Metode Akuntansi}

\section{Terhadap Penghindaran Pajak}

Metode akuntansi merupakan metode tertentu yang dipakai perusahaan sebagai dasar atau acuan dalam proses akuntansi perusahaan, seperti metode penyusutan dan metode penilaian persediaan. Selama setiap laporan keuangan menggunakan metode penyusutan atau metode penilaian persediaan yang berbeda, dapat dipastikan bahwa penghitungan laba menurut akuntansi akan sangat berbeda dengan penghitungan laba menurut fiskus yang menjadi dasar untuk menentukan berapa besarnya pajak yang terutang (Zain, 2008: 104).

Metode penyusutan akan memengaruhi besarnya beban penyusutan suatu aset dalam laporan keuangan, termasuk berpengaruh terhadap penghasilan kena pajak perusahaan. Hal ini dikarenakan dalam ketentuan perpajakan, beban penyusutan merupakan beban yang dapat dikurangkan dalam penghitungan penghasilan kena pajak. Metode penyusutan yang diperbolehkan berdasarkan Undang- 
Undang Nomor 36 Tahun 2008 adalah metode garis lurus dan metode saldo menurun. Metode garis lurus akan menyebabkan pembebanan biaya penyusutan yang tetap jumlahnya tiap periode sehingga laba yang dihasilkan setiap periode relatif konstan (Nugroho, 2006). Pada saat yang sama, mereka menggunakan metode penyusutan dipercepat (saldo menurun) pada pengembalian pajak mereka untuk meminimalkan pembayaran pajak mereka (Kieso, Weygandt, dan Kimmel, 2011: 398).

Metode penilaian persediaan yang digunakan suatu perusahaan akan memengaruhi besarnya harga pokok penjualan. Harga pokok penjualan merupakan pengurang pendapatan perusahaan yang akan memengaruhi besarnya pajak yang terutang. Menurut Undang-Undang No. 10 Tahun 1994, metode penilaian persediaan yang diperbolehkan adalah metode FIFO dan metode rata-rata. Ketika perusahaan menggunakan FIFO dalam periode inflasi, persediaan pada laporan posisi keuangan dan laba bersih pada laporan laba rugi lebih tinggi dibandingkan ketika perusahaan menggunakan metode rata-rata. Namun beberapa perusahaan menggunakan metode rata-rata karena metode ini menghasilkan pembayaran pajak yang lebih rendah, hal ini dikarenakan laba bersih yang lebih rendah selama periode inflasi (Kieso, Weygandt, dan Kimmel, 2011: 259-260). Menurut hasil penelitian Salim (2010), metode ratarata merupakan metode penilaian persediaan yang dapat meminimalkan pajak yang harus dibayar perusahaan. Oleh karena itu, perusahaan-perusahaan memanfaatkan metode penyusutan dan metode penilaian persediaan yang merupakan indikator dari metode akuntansi sebagai sarana untuk meminimalkan pajak yang terutang tanpa melanggar ketentuan perpajakan yang ada (tax avoidance).

\section{$\mathrm{H}_{2}$ : Metode Akuntansi berpengaruh terhadap penghindaran pajak.}


Pengaruh Struktur Kepemilikan Terhadap Penghindaran Pajak

Struktur kepemilikan digambarkan dalam suatu komposisi kepemilikan saham dan timbul akibat adanya perbandingan persentase saham yang dimiliki oleh pemilik saham (shareholder) dalam satu perusahaan (Gabriella, dalam Hadi dan Mangoting 2014). Salah satu kebijakan perusahaan untuk memperoleh modal perusahaan adalah dengan menerbitkan saham. Semakin banyak saham dijual, maka semakin banyak pula saham yang beredar dan saham dapat dimiliki oleh siapa saja yang membeli saham tersebut. Sebuah perusahaan dapat dimiliki oleh institusi, publik, keluarga, maupun orang dalam perusahaan tersebut (manajerial). Dalam penelitian ini, struktur kepemilikan diukur dengan menggunakan kepemilikan institusional dan kepemilikan publik sebagai indikator.

Kepemilikan institusional diukur melalui persentase kepemilikan institusional. Hasil penelitian Ngadiman dan Puspitasari (2014) dan Pranata, Puspa, dan Herawati (2014) menunjukkan bahwa kepemilikan institusional memiliki pengaruh positif dan signifikan terhadap tax avoidance, yang menunjukkan bahwa semakin besar kepemilikan institusional maka akan meningkatkan tindakan pajak agresif. Maka dari itu, besar kecilnya kepemilikan institusional diduga akan memengaruhi kebijakan pajak agresif (tax avoidance) yang dilakukan oleh perusahaan.

Kepemilikan publik diukur melalui persentase saham yang dijual kepada masyarakat (publik). Hasil penelitian Puspita dan Harto (2014) menunjukkan kepemilikan publik berpengaruh negatif dan signifikan terhadap tax avoidance, yang menunjukkan semakin besar kepemilikan publik dalam perusahaan dapat meminimalkan tindakan tax avoidance.

\section{$\mathrm{H}_{3}$ : Struktur Kepemilikan berpengaruh terhadap penghindaran pajak.}




\section{Kerangka Pemikiran}

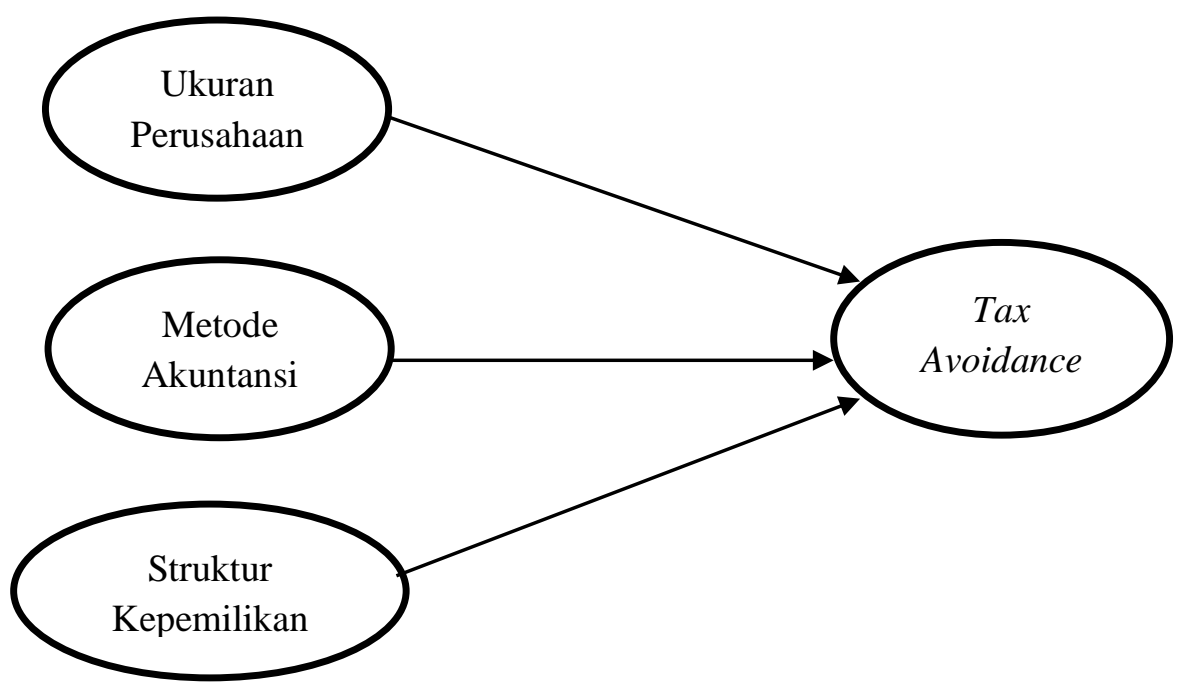

Gambar 1. Kerangka Pemikiran

\section{METODOLOGI PENELITIAN}

Peneliti menggunakan teknik pengumpulan data berupa teknik dokumentasi, yaitu dengan observasi data sekunder. Data sekunder tersebut antara lain:

1. Data laporan keuangan yang termasuk dalam perusahaan manufaktur periode 2010-2013 yang terdaftar di Bursa Efek Indonesia (BEI).

2. Data mengenai pembayaran pajak, laba sebelum pajak, total asset perusahaan, total revenue perusahaan, metode penyusutan, metode penilaian persediaan, besarnya persentase saham yang dimiliki oleh pihak-pihak institusi, besarnya persentase saham yang dimiliki oleh pihakpihak publik, yang terdapat dalam laporan keuangan audited perusahaan.

Teknik pengambilan sampel yang digunakan dalam penelitian ini adalah non-probability sampling dengan metode purposive sampling. Purposive sampling merupakan teknik pengambilan sampel secara khusus berdasarkan kriteria-kriteria tertentu (Sari, 2012). Berdasarkan pertimbangan kriteria, 27 perusahaan terpilih sebagai sampel yang akan digunakan dalam penelitian ini.

\section{Variabel Penelitian}

\section{Tax Avoidance}

Penghindaran pajak yang juga disebut sebagai tax planning, adalah 
proses pengendalian tindakan agar terhindar dari konsekuensi pengenaan pajak yang tidak dikehendaki. Penghindaran pajak adalah suatu tindakan yang benar- benar legal. Indikator dari $\operatorname{Tax}$ Avoidance adalah Cash ETR. Penelitian ini menggunakan rumus Cash ETR yang dikembangkan oleh Chen et al. (2010):

$$
\text { Cash ETR }=\frac{\text { Cash Tax Paid } i, t}{\text { Pretax Income } i, t}
$$

\section{Ukuran Perusahaan}

Ukuran perusahaan adalah suatu skala dimana dapat diklasifikasikan besar kecilnya perusahaan menurut beberapa cara, antara lain: total aset, penjualan bersih, dan kapitalisasi

$$
\begin{aligned}
& \text { SIZE }=\operatorname{Ln}(\text { Total Asset }) \\
& \text { SIZE }=\text { Ln }(\text { Total Revenue })
\end{aligned}
$$

\section{Metode Akuntansi}

Metode akuntansi adalah metode tertentu yang dipakai sebagai dasar atau acuan di dalam melakukan pengukuran, pengakuan, dan pelaporan menyangkut efek dari transaksi, peristiwa, kejadian, atau keadaan tertentu (Harnanto, 2003: 38). Indikator dari metode akuntansi adalah:

(1) Metode penyusutan, diukur dengan memberikan nilai 1 untuk metode saldo menurun dan memberikan nilai 0 untuk metode garis lurus. pasar (Fitriani dalam Andhika, 2010: 49). Ukuran perusahaan dihitung menggunakan Natural logarithm total asset dan Natural logarithm total revenue yang dimiliki oleh suatu perusahaan.

(2) Metode penilaian persediaan, diukur dengan memberikan nilai 1 untuk metode rata-rata dan memberikan nilai 0 untuk metode FIFO.

\section{Struktur Kepemilikan}

Struktur kepemilikan digambarkan dalam suatu komposisi kepemilikan saham dari suatu perusahaan dan timbul akibat adanya perbandingan persentase saham yang dimiliki oleh pemilik saham (shareholder) dalam satu perusahaan (Gabriella, dalam Hadi dan Mangoting 2014). 
(1) Kepemilikan institusional, diukur dengan besarnya persentase saham yang dimiliki oleh pihakpihak institusi.

(2) Kepemilikan publik, diukur dengan besarnya persentase saham yang dimiliki oleh pihak masyarakat atau publik.

\section{Teknik Analisis Data}

Dalam melakukan pengolahan data dan menganalisis data-data yang diperoleh untuk mendapatkan informasi yang diinginkan, peneliti menggunakan alat bantu pengolahan data berupa penggunaan software (perangkat lunak) yaitu SMARTPLS versi 3.0 yang digunakan untuk melakukan uji outer model, indikator-indikator, uji model dan hipotesis (inner model), analisis regresi data panel untuk melihat pengaruh dari variabel-variabel yang ada. Teknik analisis data menggunakan statistik berupa analisis kausalitas SEM (Structural Equation Modelling) berbasis component atau variance yang terkenal dengan Partial Least Square (PLS), karena bersifat kausal prediktif dimana akan menjadi lebih efektif. SEM lebih sesuai untuk analisis data dalam penelitian ini karena mampu menggambarkan konsep model dengan variabel laten (variabel yang tidak dapat diukur secara langsung) akan tetapi diukur melalui indikator-indikatornya (manifest variabel).

\section{Evaluasi Model Pengukuran (Outer Model)}

Evaluasi model pengukuran atau outer model dilakukan dengan menilai validitas dan reliabilitas model. Outer model dengan indikator refleksif dievaluasi melalui validitas convergent dan discriminant dari indikator pembentuk konstruk laten dan composite reliability serta cronbach alpha untuk blok indikatornya (Chin, dalam Ghozali dan Latan 2015: 73).

\section{a. Validitas Convergent}

Validitas convergent berhubungan dengan prinsip bahwa pengukur-pengukur (manifest variabel) dari suatu konstruk seharusnya berkorelasi tinggi. Uji validitas convergent indikator refleksif dapat dilihat dari nilai loading factor untuk tiap indikator konstruk. Nilai 
loading faktor $\quad 0.5-0.6$

dianggap cukup (Chin, dalam

Ghozali dan Latan 2015: 74).

\section{b. Validitas Discriminant}

Validitas discriminant

berhubungan dengan prinsip bahwa pengukur-pengukur konstruk yang berbeda seharusnya tidak berkorelasi tinggi (Ghozali dan Latan, 2015: 74). Cara untuk menguji validitas discriminant dengan indikator refleksif yaitu dengan melihat nilai cross loading dari setiap variabel harus >0.70 Cara lain yang dapat digunakan adalah dengan membandingkan akar kuadrat dari Average Variance Extracted (AVE) untuk setiap konstruk dengan nilai korelasi antar konstruk dalam model. Nilai AVE yang direkomendasikan harus lebih besar dari 0.50 yang mempunyai arti bahwa 50\% atau lebih variance dari indikator dapat dijelaskan.

\section{c. Reliabilitas Konstruk}

Uji reliabilitas dilakukan untuk membuktikan akurasi, konsistensi, dan ketepatan istrumen dalam mengukur konstruk (Ghozali dan Latan, 2015: 75). Penggunaan Cronbach's Alpha untuk menguji reliabilitas konstruk akan memberikan nilai yang lebih rendah (under estimate) sehingga lebih disarankan untuk menggunakan Composite Reliability. Nilai Composite Reliability harus lebih besar dari 0.7 untuk penelitian yang bersifat confirmatory dan nilai 0.6 0.7 masih dapat diterima untuk penelitian yang bersifat exploratory.

\section{Evaluasi Model Struktural} (Inner Model)

\section{a. Signifikansi}

(Estimasi

\section{Koefisien Jalur)}

Nilai estimasi koefisien jalur antara konstruk harus memiliki nilai yang signifikan. Nilai signifikansi untuk mengetahui pengaruh antar variabel dapat diperoleh dengan prosedur 
Pengaruh Ukuran Perusahaan, Metode Akuntansi, dan Struktur Kepemilikan Terhadap Tax Avoidance pada Perusahaan Manufaktur yang Terdaftar di Bursa Efek Indonesia

Periode 2010-2013

bootstrapping atau
jackknifing (Ghozali dan
Latan, 2015: 80). Nilai yang
dihasilkan berupa nilai t-
hitung yang kemudian
dibandingkan dengan t-tabel.
Apabila nilai t-hitung $>$ t-
tabel (1.96) pada taraf
signifikasi $(\alpha$ 5\%) maka nilai
estimasi koefisien jalur
tersebut signifikan.

4. HASIL \& ANALISIS

Pengujian hipotesis dalam penelitian ini menggunakan metode Partial Least Square (PLS). PLS merupakan metode alternatif analisis dengan Structural Equation Modelling (SEM) yang berbasis variance. Keunggulan metode ini adalah tidak memerlukan asumsi dan dapat diestimasi dengan jumlah sampel yang relatif kecil. Alat bantu yang digunakan berupa program SmartPLS versi 3.0. Model struktural dalam penelitian ini ditampilkan pada gambar di bawah:

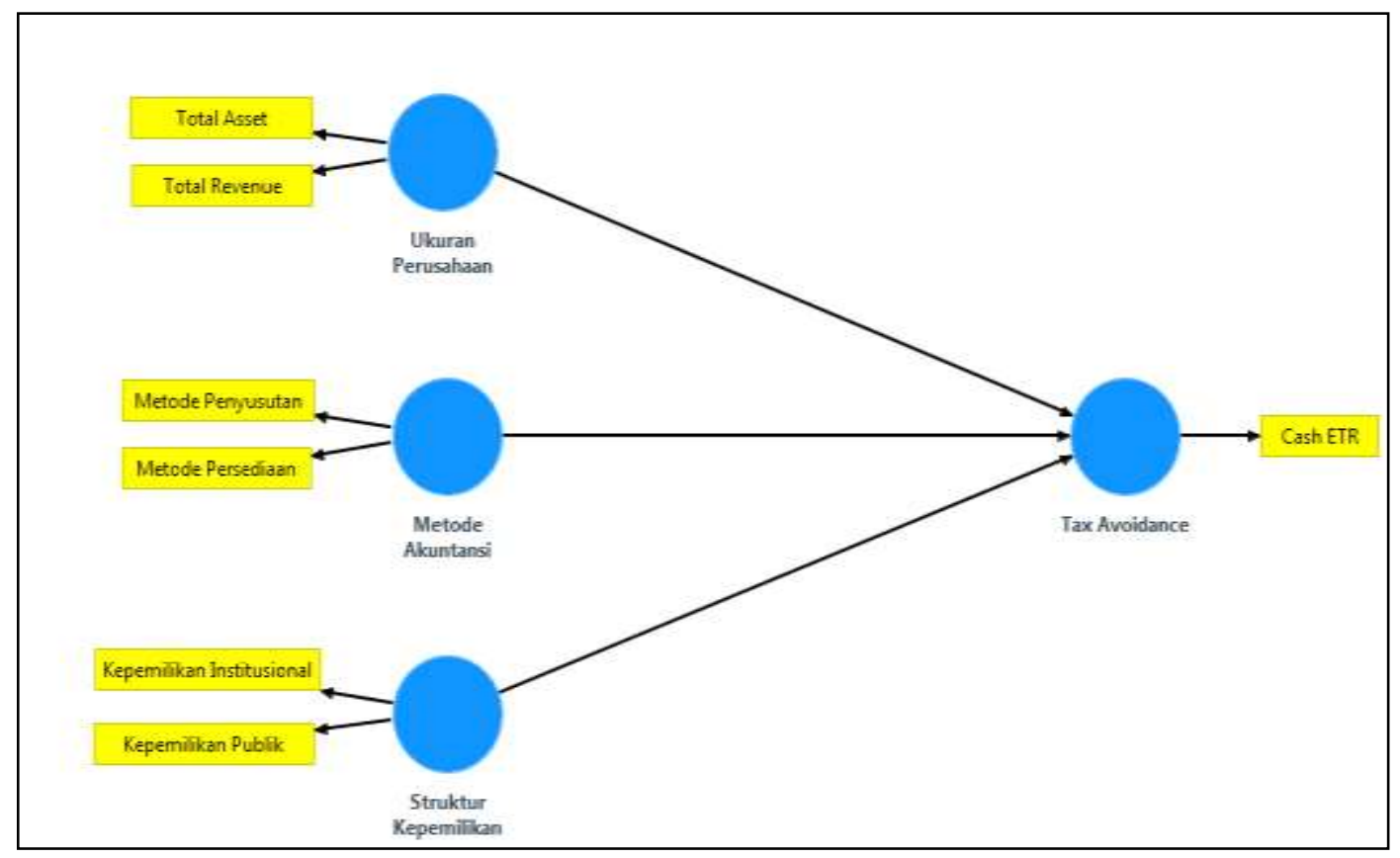

Gambar 2. Gambar Model Struktural

Sumber : Olahan PLS

Gambar di atas menunjukkan bahwa konstruk Ukuran Perusahaan diukur dengan dua indikator, yaitu Total Asset dan Total Revenue. Konstruk 
Metode Akuntansi diukur dengan dua indikator, yaitu Metode Penyusutan dan Metode Persediaan. Konstruk Struktur Kepemilikan diukur dengan dua indikator, yaitu Kepemilikan Institusional dan Kepemilikan Publik. Konstruk Tax Avoidance diukur dengan satu indikator, yaitu Cash ETR.

Arah panah antara indikator dengan konstruk laten Ukuran Perusahaan, Metode Akuntansi, Struktur Kepemilikan, dan antara indikator dengan konstruk laten Tax
Avoidance adalah menuju indikator yang menunjukkan bahwa penelitian menggunakan indikator refleksif. Hubungan yang akan diteliti (hipotesis) dilambangkan dengan anak panah antara konstruk.

\section{Validitas Convergent}

Suatu indikator dikatakan valid jika mempunyai loading factor di atas 0.5 terhadap konstruk yang dituju. Berikut adalah diagram loading factor masing-masing indikator dalam model penelitian:

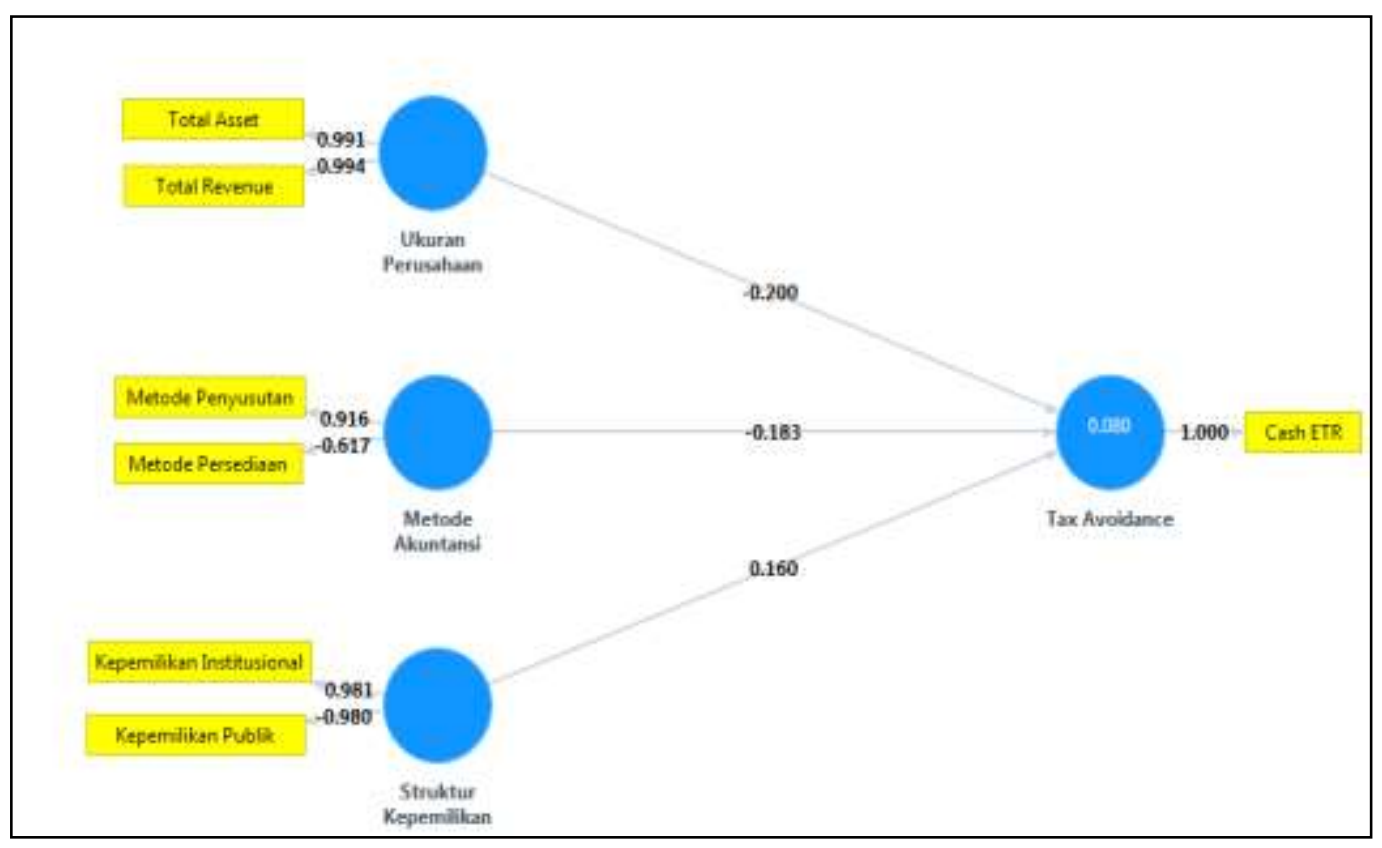

Gambar 3. Nilai Loading Factor

Sumber : Olahan PLS 
Berdasarkan gambar di atas nilai loading factor pada indikatorindikator konstruk laten Ukuran Perusahaan, Metode Akuntansi, Struktur Kepemilikan, dan Tax Avoidance adalah sebagai berikut:

1) Nilai loading factor sebesar 0.991 untuk indikator Total Asset, yakni di atas nilai yang disarankan yaitu 0.5 sehingga Total Asset dinyatakan valid.

2) Nilai loading factor sebesar 0.994 untuk indikator Total Revenue, yakni di atas nilai yang disarankan yaitu 0.5 sehingga Total Revenue dinyatakan valid.

3) Nilai loading factor sebesar 0.916 untuk indikator Metode Penyusutan, yakni di atas nilai yang disarankan yaitu 0.5 sehingga Metode Penyusutan dinyatakan valid.

4) Nilai loading factor sebesar 0.617 untuk indikator Metode Persediaan, yakni di bawah nilai yang disarankan yaitu 0.5 sehingga Metode Persediaan dinyatakan tidak valid dan harus dikeluarkan dari model.

5) Nilai loading factor sebesar 0.981 untuk indikator Kepemilikan Institusional, yakni di atas nilai yang disarankan yaitu 0.5 sehingga Kepemilikan Institusional dinyatakan valid.

6) Nilai loading factor sebesar 0.980 untuk indikator Kepemilikan Publik, yakni di bawah nilai yang disarankan yaitu 0.5 sehingga Kepemilikan Publik dinyatakan tidak valid dan harus dikeluarkan dari model.

7) Nilai loading factor sebesar 1.000 untuk indikator Cash ETR, yakni di atas nilai yang disarankan yaitu 0.5 sehingga Cash ETR dinyatakan valid.

Model re-estimasi kembali dengan membuang indikator Metode Persediaan dan Kepemilikan Publik menjadi: 


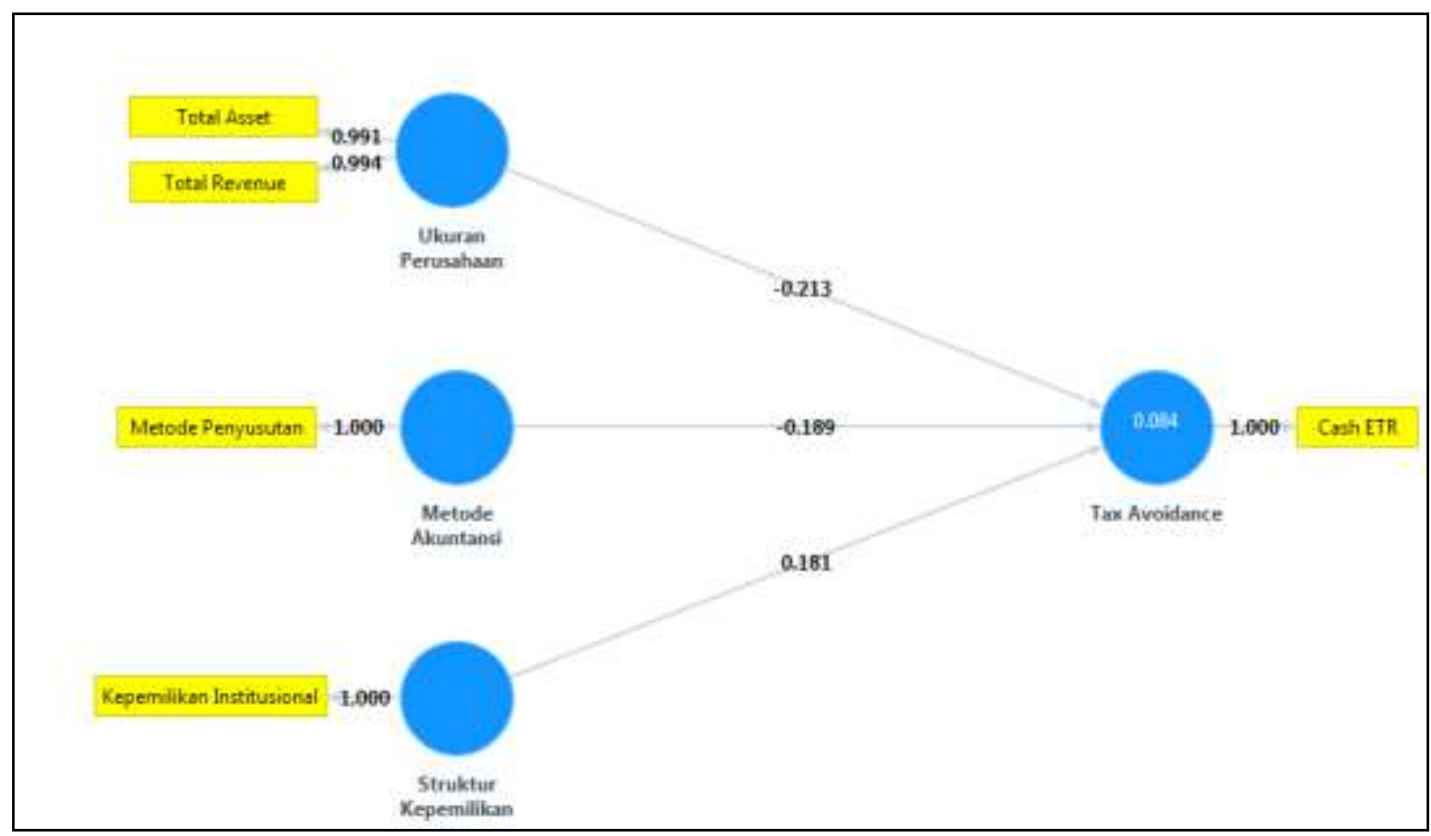

Gambar 4. Re-estimasi Model 1

Sumber : Olahan PLS

\section{Validitas Discriminant}

Indikator refleksif juga perlu diuji discriminant validity. Suatu indikator dikatakan valid jika memiliki loading factor tertinggi kepada konstruk yang dituju dibandingkan loading factor kepada konstruk lain. Pengujian discriminant validity dilakukan dengan cara cross loading sebagai berikut:

Tabel 1. Hasil Cross Loading

Cosastoerings

\begin{tabular}{|c|c|c|c|c|}
\hline & 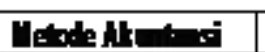 & 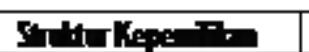 & $T=k r x^{!} ! x_{x}$ & 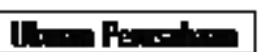 \\
\hline CWIEIR & $-0,14 \mathbb{F}$ & 0,138 & 1000 & $-0,10$ \\
\hline 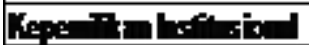 & 0,025 & 1,000 & 0,138 & 0,178 \\
\hline 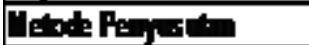 & 1,000 & 0,025 & $-0,147$ & $-0,173$ \\
\hline Idt/tromt & $-0,181$ & 0,158 & $-0,130$ & 0991 \\
\hline Idt Perene & $-0,16 \mathrm{~A}$ & 0,192 & $-0,161$ & 099 \\
\hline
\end{tabular}

Sumber: Olahan PLS

Tabel di atas menunjukkan bahwa loading factor untuk indikator Total Asset kepada konstruk Ukuran Perusahaan memiliki nilai lebih tinggi daripada dengan konstruk lainnya, yaitu 0.991 lebih besar daripada $-0.181,0.158$, dan -0.130 . Hal serupa juga tampak pada loading factor untuk indikator Total Revenue kepada konstruk Ukuran Perusahaan 
memiliki nilai lebih tinggi daripada dengan konstruk lainnya, yaitu 0.994 lebih besar daripada -0.164, 0.192, dan -0.161. Hal serupa juga tampak pada loading factor untuk indikator Metode Penyusutan kepada konstruk Metode Akuntansi memiliki nilai lebih tinggi daripada dengan konstruk lainnya, yaitu 1.000 lebih besar daripada $0.025,-0.147$, dan 0.173 .

Hal serupa juga tampak pada loading factor untuk indikator Kepemilikan Institusional kepada konstruk Struktur Kepemilikan memiliki nilai lebih tinggi daripada dengan konstruk lainnya, yaitu 1.000 lebih besar daripada $0.025,0.138$, dan
0.178. Hal serupa juga tampak pada loading factor untuk indikator Cash ETR kepada konstruk Tax Avoidance memiliki nilai lebih tinggi daripada dengan konstruk lainnya, yaitu 1.000 lebih besar daripada $-0.147,0.138$, dan -0.149 .

Dengan demikian, konstruk laten memprediksi indikator pada blok mereka lebih baik dibandingkan dengan indikator di blok yang lain. Metode lain untuk melihat discriminant validity adalah dengan melihat nilai square root of average variance extracted (AVE). Nilai yang disarankan adalah di atas 0.5. Berikut adalah nilai AVE dalam penelitian ini:

Tabel 2. Average Variance Extracted (AVE)

\begin{tabular}{|c|c|}
\hline & AVE \\
\hline Telode Akedringi & 1,01:D \\
\hline 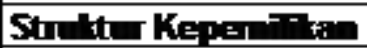 & 1,010 \\
\hline Iax Avoldice & 1,0:1] \\
\hline 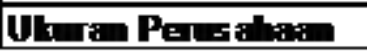 & 0,965 \\
\hline
\end{tabular}

Sumber: Olahan PLS

Tabel di atas memberikan nilai AVE di atas 0.5 untuk Ukuran Perusahaan, Metode Akuntansi, Struktur Kepemilikan, dan Tax Avoidance, maka konstruk Ukuran Perusahaan, Metode Akuntansi,
Struktur Kepemilikan, dan Tax Avoidance dinyatakan valid.

\section{Reliabilitas Konstruk}

Uji reliabilitas dilakukan dengan melihat nilai composite reliability dari blok indikator yang mengukur 
konstruk. Hasil composite reliability akan menunjukkan nilai memuaskan jika di atas 0.7. Berikut adalah nilai composite reliability pada output:

Tabel 3. Composite Reliability

\begin{tabular}{|c|c|}
\hline & 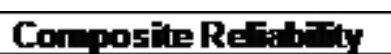 \\
\hline Telode Akedrien & 1,0ind \\
\hline Sthlo Kepel'-ian & 1,010 \\
\hline Tax Avo'il:ace & 1,0II) \\
\hline Ularin Pelcallativ & 0,993 \\
\hline
\end{tabular}

Sumber : Olahan PLS

Tabel di atas menunjukkan bahwa nilai composite reliability untuk semua konstruk di atas 0.7 yang menunjukkan bahwa semua konstruk pada model yang diestimasi memenuhi kriteria discriminant validity.

Uji reliabilitas juga bisa dilihat melalui Cronbach's Alpha. Namun, penggunaan Cronbach's Alpha untuk menguji reliabilitas konstruk akan memberikan nilai yang lebih rendah (under estimate) sehingga lebih disarankan untuk menggunakan Composite Reliability (Ghozali dan Latan, 2015: 75).

\section{Signifikansi (Estimasi Koefisien Jalur)}

Untuk mengetahui signifikasi hubungan dan pengaruh antar variabel dapat diperoleh dengan prosedur Bootstrapping yang bisa dilihat dari model di bawah ini:

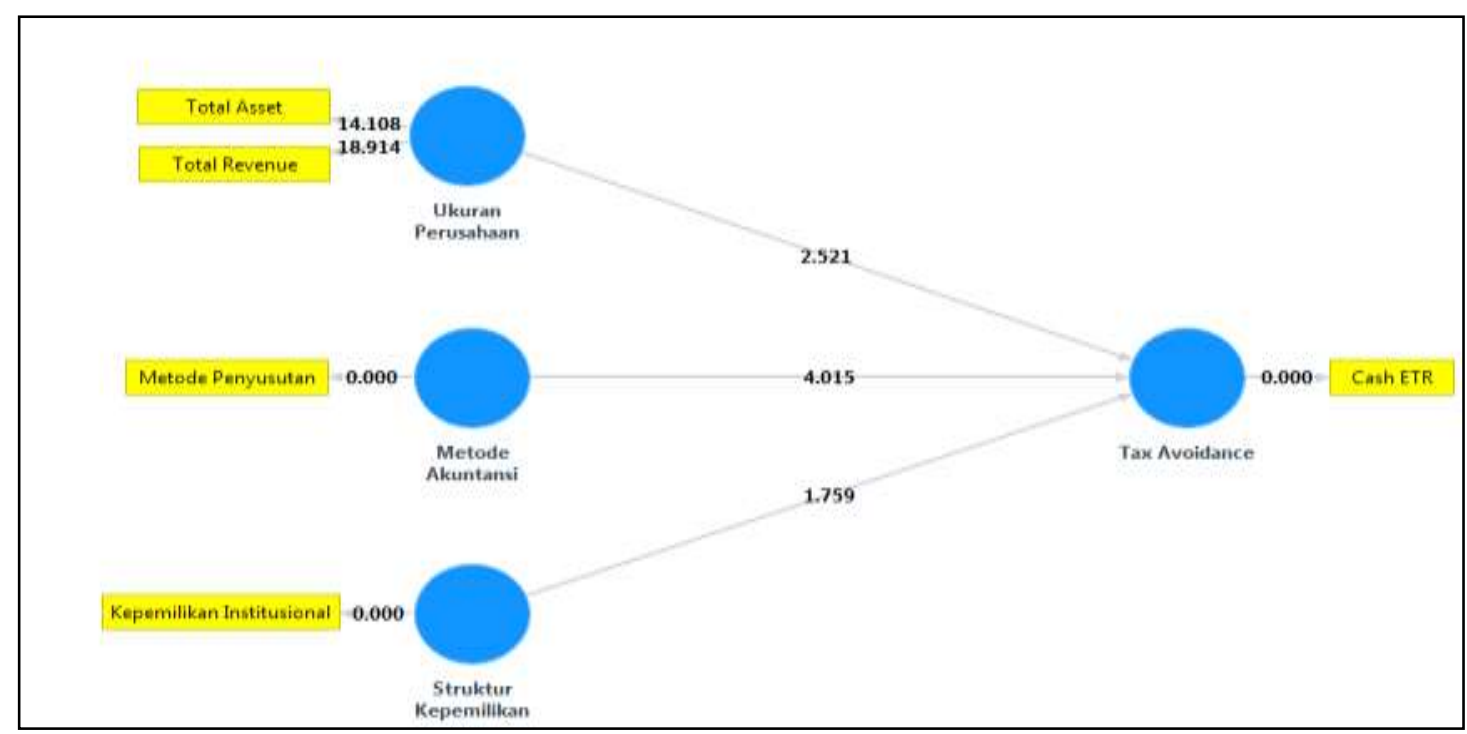

Gambar 4. Model Koefisien Jalur (Path Coefficient Model)

Sumber: Olahan PLS 
Tabel 4. Uji Hipotesis

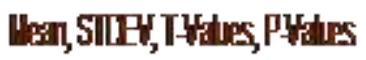

\begin{tabular}{|c|c|c|c|c|c|}
\hline & 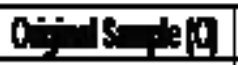 & shen & 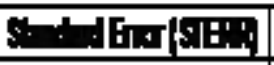 & Ts:or & PHh: \\
\hline 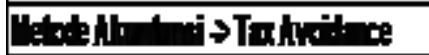 & 0,0100 & $-0,190$ & 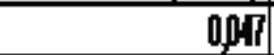 & 1075 & 0,000 \\
\hline 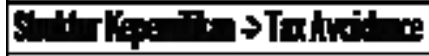 & 0,101 & $Q, 78$ & 0,103 & 1,759 & 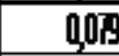 \\
\hline 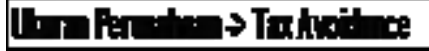 & 0213 & Q213 & 00900 & 2,51 & QOD \\
\hline
\end{tabular}

Sumber : Olahan PLS

Tabel di atas menunjukkan bahwa hubungan antara Ukuran Perusahaan dengan Tax Avoidance signifikan karena T-statistic sebesar 2.521 $(>1,96)$. Dengan demikian maka Hipotesis 1 yang berbunyi "Ukuran Perusahaan berpengaruh terhadap Penghindaran Pajak" dapat diterima.

Tabel di atas menunjukkan bahwa hubungan antara Metode Akuntansi dengan Tax Avoidance signifikan karena T-statistic sebesar 4.015 ( $>1,96)$. Dengan demikian maka Hipotesis 2 yang berbunyi "Metode Akuntansi berpengaruh terhadap Penghindaran Pajak" dapat diterima. Tabel di atas menunjukkan bahwa hubungan antara Struktur Kepemilikan dengan Tax Avoidance tidak signifikan karena $T$-statistic sebesar 1.759 (tidak>1,96). Dengan demikian maka Hipotesis 3 yang berbunyi "Struktur Kepemilikan berpengaruh terhadap Penghindaran Pajak" tidak terdapat cukup bukti.

\section{PEMBAHASAN}

\section{Pengaruh Ukuran Perusahaan terhadap Penghindaran Pajak}

Dalam hasil path coefficient, variabel Ukuran Perusahaan memiliki nilai $T$ statistic sebesar 2.521. Berdasarkan penelitian yang dilakukan dapat dikatakan bahwa terdapat cukup bukti bahwa Ukuran Perusahaan berpengaruh terhadap Penghindaran Pajak. Hal ini dapat dilihat dari nilai $T$-statistic sebesar 2.521 dimana nilai ini lebih besar dari 1.96 (> 1.96). Hasil penelitian ini sejalan dengan hipotesis yang diajukan penulis.

Ukuran perusahaan yang diwakili oleh total asset dan total revenue berpengaruh terhadap penghindaran pajak. Semakin besar total asset dan total revenue mengindikasikan semakin besar pula ukuran perusahaan tersebut. Semakin besar ukuran perusahaan yang dilihat dari indikator total asset maka semakin banyak sumber daya yang dimiliki perusahaan, sedangkan semakin 
besar ukuran perusahaan yang dilihat dari indikator total revenue maka semakin besar laba yang diperoleh perusahaan tersebut. Laba yang semakin besar menunjukkan beban pajak yang semakin besar, sehingga hal ini diduga dapat membuat perusahaan untuk semakin melakukan tindakan tax avoidance. Namun, di sisi lain diduga perusahaan dengan ukuran yang lebih besar memiliki kemungkinan menjadi pusat perhatian pemerintah sehingga lebih sulit untuk melakukan tax avoidance. Maka dari itu, perusahaan dengan ukuran yang lebih besar dianggap mampu membayar kewajibannya dibandingkan dengan perusahaan dengan ukuran yang lebih kecil.

Hasil penelitian ini sejalan dengan hasil penelitian Waluyo, Basri, dan Rusli (2015) yang menyatakan bahwa ukuran perusahaan berpengaruh secara positif terhadap tax avoidance. Hal ini diduga karena perusahaan besar lebih memiliki sumber daya yang lebih banyak dan aktivitas operasi yang lebih rumit sehingga terdapat celah-celah untuk dimanfaatkan dalam keputusan tax avoidance. Sedangkan perusahaan kecil memiliki sumber daya relatif sedikit dan aktivitas yang masih terbatas, sehingga sedikit sulit untuk melakukan tax avoidance.

Hasil penelitian ini juga sejalan dengan hasil penelitian Kurniasih dan Sari (2013) dan Ngadiman dan Puspitasari (2014) yang menyimpulkan bahwa ukuran perusahaan berpengaruh secara negatif terhadap tax avoidance yang menunjukkan bahwa semakin besar ukuran perusahaan maka perusahaan tersebut cenderung untuk meminimalkan tindakan penghindaran pajak. Hal ini dikarenakan perusahaan tidak selalu dapat menggunakan power yang dimilikinya untuk melakukan perencanaan pajak karena adanya batasan berupa kemungkinan menjadi sorotan dan sasaran dari keputusan regulator - political cost theory (Watts dan Zimmerman, 1978). Namun, hasil penelitian ini tidak sejalan dengan hasil penelitian Puspita dan Harto (2015) yang menyatakan bahwa ukuran perusahaan tidak berpengaruh secara signifikan terhadap penghindaran pajak. 
Arah pengaruh ukuran perusahaan terhadap penghindaran pajak ini tergantung kepada perilaku manajer sebagai agen dari pemilik perusahaan yang melakukan tindakan tax avoidance. Perilaku manajer dalam perusahaan adalah relatif, dimana tidak terdapat ukuran pasti.

\section{Pengaruh Metode Akuntansi terhadap Penghindaran Pajak}

Dalam hasil path coefficient, variabel Metode Akuntansi memiliki nilai $T$ statistic sebesar 4.015. Berdasarkan penelitian yang dilakukan dapat dikatakan bahwa terdapat cukup bukti bahwa Metode Akuntansi berpengaruh terhadap Penghindaran Pajak. Hal ini dapat dilihat dari nilai $T$-statistic sebesar 4.015 dimana nilai ini lebih besar dari 1.96 (> 1.96). Hasil penelitian ini sejalan dengan hipotesis yang diajukan penulis.

Zain (2008: 104) menjelaskan bahwa penggunaan metode penyusutan atau metode penilaian persediaan yang berbeda, dapat dipastikan bahwa penghitungan laba menurut akuntansi akan sangat berbeda dengan penghitungan laba menurut fiskus yang menjadi dasar untuk menentukan berapa besarnya pajak yang terutang, sehingga perusahaanperusahaan memanfaatkan metode penyusutan dan metode penilaian persediaan yang merupakan indikator dari metode akuntansi sebagai sarana untuk meminimalkan pajak terutang mereka tanpa melanggar ketentuan perpajakan yang ada (tax avoidance). Metode akuntansi yang diwakili oleh metode penyusutan berpengaruh terhadap penghindaran pajak, diduga karena nilai aktiva tetap perusahaanperusahaan umumnya cukup besar bahkan dapat mencapai $50 \%$ dari total aset yang ada. Aktiva tetap ini akan disusutkan dan dibebankan sebagai biaya penyusutan aktiva tetap oleh perusahaan. Biaya penyusutan aktiva tetap tersebut akan menjadi pengurang pendapatan perusahaan sehingga laba perusahaan berkurang dan pajak terutang perusahaan pun akan berkurang. Banyak perusahaan menggunakan metode penyusutan tertentu yang dapat mengatur pembayaran pajak yang seoptimal mungkin, baik itu metode garis lurus maupun metode saldo menurun. Penentuan metode yang digunakan suatu perusahaan dipertimbangkan dari berbagai faktor kondisi perusahaan masing-masing, 
seperti umur aktiva, nilai total aktiva, dan lain-lain.

\section{Pengaruh Struktur Kepemilikan terhadap Penghindaran Pajak}

Dalam hasil path coefficient, variabel Struktur Kepemilikan memiliki nilai T-statistic $\quad$ sebesar $\quad 1.759$. Berdasarkan penelitian yang dilakukan dapat dikatakan bahwa tidak terdapat cukup bukti bahwa Struktur Kepemilikan berpengaruh terhadap Penghindaran Pajak. Hal ini dapat dilihat dari nilai T-statistic sebesar 1.759 dimana nilai ini lebih kecil dari 1.96 (tidak > 1.96). Hasil penelitian ini tidak sejalan dengan hipotesis yang diajukan penulis.

Struktur Kepemilikan yang diwakili oleh kepemilikan institusional tidak cukup bukti berpengaruh terhadap penghindaran pajak. Hasil penelitian ini mengindikasikan bahwa besar atau kecilnya suatu struktur kepemilikan dari indikator kepemilikan institusional pada perusahaan tidak memengaruhi penghindaran pajak. Hal itu diduga karena yang melakukan tax avoidance adalah pihak manajemen. Institusi selaku pemilik hanya memberikan wewenang kepada manajer agar berfokus pada kinerja yang baik, selebihnya merupakan tugas manajemen untuk mengelola perusahaan termasuk urusan perpajakannya, maka diduga tidak ada pengaruh besar kecilnya kepemilikan institusional terhadap tax avoidance.

Hasil penelitian ini sejalan dengan hasil penelitian Waluyo, Basri, dan Rusli (2015) yang menyimpulkan bahwa kepemilikan institusional tidak berpengaruh signifikan terhadap penghindaran pajak. Namun, hasil penelitian ini tidak sejalan dengan hasil penelitian Ngadiman dan Puspitasari (2014) dan Pranata, Puspa, dan Herawati (2014) yang menunjukkan bahwa terdapat pengaruh positif dan signifikan antara kepemilikan institusional terhadap penghindaran pajak.

Hal ini juga sesuai dengan Teori Agensi (Agency Theory), dimana pihak institusi memberikan wewenang kepada manajer untuk mengambil keputusan-keputusan yang menghasilkan kinerja perusahaan yang baik, sehingga manajer bertanggung jawab untuk mengambil keputusan yang 
memaksimumkan kemakmuran pihak institusi. Oleh karena itu, dari hasil penelitian ini diduga bahwa bukanlah pihak institusi yang memengaruhi timbulnya perilaku tax avoidance, melainkan pihak manajemen. Pihak manajemen bertanggung jawab sebagai pengelola perusahaan dan lebih banyak mengetahui informasi internal, sehingga diduga manajemen dalam perusahaan merupakan pihak yang dapat membuat keputusan-keputusan untuk mengatur perpajakan yang memicu timbulnya praktik tax avoidance.

\section{KESIMPULAN}

Berdasarkan dari data yang sudah diolah dan pengujian analisis data yang sudah dilakukan, maka dapat diambil kesimpulan bahwa Ukuran Perusahaan berpengaruh terhadap penghindaran pajak, Metode Akuntansi berpengaruh terhadap penghindaran pajak, dan Struktur Kepemilikan tidak berpengaruh terhadap penghindaran pajak.

Beberapa saran untuk penelitian selanjutnya adalah bagi peneliti selanjutnya yang tertarik meneliti judul yang sama, diharapkan mampu menambah sampel penelitian misalnya menambah kategori perusahaan yang terdaftar di BEI dan tidak terbatas pada perusahaan manufaktur saja, seperti Sektor Keuangan, Sektor Pertambangan, Sektor Perdagangan, Jasa, dan Investasi, dan lain lain. Bagi peneliti yang akan datang diharapkan untuk menambah periode tahun penelitian, karena penghindaran pajak dapat dilakukan secara jangka panjang. Untuk peneliti selanjutnya yang ingin meneliti judul yang sama agar dapat mempertimbangkan faktorfaktor lain yang mempengaruhi Tax Avoidance, seperti Corporate Social Responsibility (CSR), kualitas audit, dan komisaris independen. Untuk proksi pengukuran Tax Avoidance peneliti selanjutnya dapat menggunakan proksi pengukuran lainnya, seperti Current Efectif Tax Rate (Current ETR) dan Book Tax Gap. 


\section{DAFTAR PUSTAKA}

Andhika, Bayu (2010), Skripsi: Pengaruh Mekanisme Corporate Governance dan Ukuran Perusahaan Terhadap Manajemen Laba dan Nilai Perusahaan Pada Perusahaan Manufaktur yang Terdaftar di BEI Periode 2004-2008, IBII.

Ayu R., Stephana Dyah dan Rini Hastuti (2009), Persepsi Wajib Pajak: Dampak Pertentangan Diametral pada Tax Evasion Wajib Pajak dalam Aspek Kemungkinan Terdeteksinya Kecurangan, Keadilan, Ketepatan Pengalokasian, Teknologi Sistem Perpajakan, dan Kecenderungan Personal (Studi Wajib Pajak Orang Pribadi), Kajian Akuntansi, Februari 2009, Hal. 1-12.

Bachtiar (2015), Skripsi: Pengaruh Struktur Kepemilikan, Ukuran Perusahaan, dan Capital Intensity Terhadap Effective Tax Rate (ETR) Pada Perusahaan Manufaktur yang Terdaftar di BEI Periode 2011-2013, Universitas Diponegoro.

Budiman, Judi dan Setiyono (2012), Pengaruh Karakter Eksekutif Terhadap Penghindaran Pajak (Tax Avoidance), Simposium Nasional Akuntansi XVIII, Medan, 16-19 September 2015.
Bursa Efek Indonesia, www.idx.co.id, diakses tanggal 28 November 2015.

Chen, S. et al (2010), Are Family Firms More Tax Avoidance Aggressive Than Non-Family Firms?, Journal of Financial Economics, Vol. 95, pp. 4161.

Dyreng, Scott D., Michelle Hanlon, dan Edward L. Maydew (2007), Long-Run Corporate Tax Avoidance, Accounting Review, Vol. 83, No. 1.

Ghozali, Imam dan Hengky Latan (2015), Partial Least Squares: Konsep, Teknik, dan Aplikasi Menggunakan Program SMARTPLS 3.0, Edisi 2, Semarang: Badan Penerbit Universitas Diponegoro.

Hadi, Junilla dan Yenni Mangoting (2014), Pengaruh Struktur Kepemilikan dan Karakteristik Dewan Terhadap Agresivitas Pajak, Tax \& Accounting Review, Vol. 4, No. 2.

Harnanto (2003), $\quad$ Akuntansi
Perpajakan, Edisi 1,
Yogyakarta: Penerbit BPFE.

IDX Watch 2010-2011 Tenth Edition (2010), Jakarta: Pustaka Bisnis Indonesia.

IDX Watch 2011-2012 Eleventh Edition (2011), Jakarta: Pustaka Bisnis Indonesia. 
Pengaruh Ukuran Perusahaan, Metode Akuntansi, dan Struktur Kepemilikan Terhadap

Tax Avoidance pada Perusahaan Manufaktur yang Terdaftar di Bursa Efek Indonesia

Periode 2010-2013

IDX Watch 2012-2013 Twelfth Edition (2012), Jakarta: Pustaka Bisnis Indonesia.

IDX Watch 2013-2014 Thirteenth Edition (2013), Jakarta: Pustaka Bisnis Indonesia.

Jensen, Michael C. dan William H. Meckling (1976), Theory of The Firm: Managerial Behavior, Agency Costs and Ownership Structure, Journal of Financial Economics, Vol. 3, No. 4, pp. 305-360.

Kieso, Donald E., Jerry J. Weygandt, dan Paul D. Kimmel (2011), Financial Accounting IFRS Edition, United States of America: John Willey \& Sons, Inc.

Kurniasih, T. dan R. Sari (2013), Pengaruh Return on Asset, Leverage, Corporate Governance, Ukuran Perusahaan dan Kompensasi Rugi Fiskal pada Tax Avoidance, Buletin Studi Ekonomi, Vol. 18, No.1, Hal. 58-66.

Ngadiman dan Puspitasari C. (2014), Pengaruh Leverage, Kepemilikan Institusional, dan Ukuran Perusahaan Terhadap Penghindaran Pajak (Tax Avoidance) pada Perusahaan Sektor Manufaktur yang Terdaftar di Bursa Efek Indonesia 20102012, Jurnal Akuntansi. Vol. XVIII, No. 03, September 2014, Hal. 408-421.
Nugroho, Andy Harom (2006), Skripsi: Analisis Penerapan Metode Penyusutan Aktiva Tetap dan Pengaruhnya Terhadap Laba Perusahaan (Studi Kasus pada Tomodachi Restoran), Universitas Widyatama.

Pradipta, Dyah H. dan Supriyadi (2015), Pengaruh Corporate Social Responsibility (CSR), Profitabilitas, Leverage, dan Komisaris Independen Terhadap Praktik Penghindaran Pajak, Simposium Nasional Akuntansi XVIII, Medan, 1619 September 2015.

Pranata, Febri Mashudi, Dwi Fitri Puspa, dan Herawati (2014), Pengaruh Karakter Eksekutif dan Corporate Governance Terhadap Tax Avoidance, EJournal Universitas Bung Hatta, Vol. 4, No. 1.

Puspita, Silvia Ratih dan Puji Harto (2014), Pengaruh Tata Kelola Perusahaan Terhadap Penghindaran Pajak, Diponegoro Journal of Accounting, Vol. 3, No. 2.

Republik Indonesia. 1994. UndangUndang Nomor 10 Tahun 1994 Tentang Perubahan Keempat Atas UndangUndang Nomor 7 Tahun 1993 Tentang Pajak Penghasilan. Lembaran Negara RI Tahun 1994, No. 3567. Sekretariat Negara. Jakarta. 
Republik Indonesia. 2008. UndangUndang Nomor 36 Tahun 2008 Tentang Perubahan Keempat Atas UndangUndang Nomor 7 Tahun 1983 Tentang Pajak Penghasilan. Lembaran Negara RI Tahun 2008, No. 133. Sekretariat Negara. Jakarta.

Rusydi, M. Khoiru dan Dwi Martani (2014), Pengaruh Struktur Kepemilikan Terhadap Agressive Tax Avoidance, Simposium Nasional Akuntansi XVII, Mataram, 24-27 September 2014.

Salim, Fika (2010), Skripsi: Perbandingan Metode Penilaian Persediaan yang Diperbolehkan oleh Undangundang Pajak Penghasilan dan Pengaruhnya Terhadap Meminimalkan Pajak

Penghasilan Terutang (Studi Kasus pada PT CANDRATEX, Bandung), Universitas Kristen Maranatha.

Santoso (2014), Skripsi: Pengaruh Corporate Governance Terhadap Penghindaran Pajak Perusahaan, Universitas Diponegoro.
Sari, Gusti M. (2012), Pengaruh Corporate Governance, Ukuran Perusahaan, Kompensasi Rugi Fiskal dan Struktur Kepemilikan terhadap Tax Avoidance, diakses 27 Oktober 2015, http://ejournal.unp.ac.id/stude nts/index.php/akt/article/view File/1601/1224

Standar Akuntansi Keuangan Per 1 Juni 2012 (2012), Jakarta: Ikatan Akuntansi Indonesia.

Waluyo, Teguh M., Yessi Mutia Basri, dan Rusli (2015), Pengaruh Return on Asset, Leverage, Ukuran Perusahaan, Kompensasi Rugi Fiskal dan Kepemilikan Institusi Terhadap Penghindaran Pajak, Simposium Nasional Akuntansi XVIII, Medan, 1619 September 2015.

Watts, Ross L. dan Jerold L. Zimmerman (1990), Positive Accounting Theory: A Ten Year Perspective, The Accounting Review, Vol. 65, No. 1, pp. 131-156.

Watts, Ross L. dan Jerold L. Zimmerman (1978), Towards a Positive Theory of the Determination of Accounting Standards, The Accounting Review, Vol. LIII, No. 1, pp. 112-134.

Zain, Mohammad (2008), Manajemen Perpajakan, Edisi 3, Jakarta: Salemba Empat. 